\title{
CROPS AND SOILS RESEARCH PAPER \\ Is it necessary to split nitrogen fertilization for winter wheat? On-farm research on Luvisols in South-West Germany
}

\author{
R. SCHULZ ${ }^{1}$, T. MAKARY ${ }^{1}$, S. HUBERT ${ }^{2}$, K. HARTUNG $^{3}$, S. GRUBER ${ }^{4}$, S. DONATH ${ }^{1}$, J. DÖHLER ${ }^{1}$, \\ K. WEI ${ }^{5}$, E. EHRHART ${ }^{6}$, W. CLAUPEIN ${ }^{4}$, H.-P. PIEPHO ${ }^{3}$, C. PEKRUN ${ }^{4}$ AND T. MÜLLER ${ }^{1 *}$ \\ ${ }^{1}$ Institute of Crop Science: Fertilization and Soil Matter Dynamics (340i), University of Hohenheim, D-70593 Stuttgart, \\ Germany \\ ${ }^{2}$ Nuertingen-Geislingen University, Agronomy, D-72622 Nürtingen, Germany \\ ${ }^{3}$ Institute of Crop Science: Bioinformatics (340C), University of Hohenheim, D-70593 Stuttgart, Germany \\ ${ }^{4}$ Institute of Crop Science: Agronomy (340a), University of Hohenheim, D-70593 Stuttgart, Germany \\ ${ }^{5}$ Landratsamt Tübingen, 72072 Tübingen, Germany \\ ${ }^{6}$ Regierungspräsidium Tübingen, 72072 Tübingen, Germany
}

(Received 4 October 2012; revised 3 December 2013; accepted 21 March 2014; first published online 1 May 2014)

\section{SUMMARY}

Mineral nitrogen $(\mathrm{N})$ fertilization in cereals is commonly split into three or four applications. In order to simplify $\mathrm{N}$ fertilization, a single $\mathrm{N}$ application either broadcast or placed on the soil surface was compared to conventionally split fertilization for winter wheat (Triticum aestivum L.). The 4-year experiment (2007-2010) was performed using a participatory approach on farmers' fields on deep loamy soils (Luvisols) in South-West Germany.

Grain yield and crude protein contents differed only slightly or not at all between treatments including different $\mathrm{N}$ fertilizer types (calcium ammonium nitrate, urea ammonium nitrate solution, urea) and application techniques (broadcast, placed). Furthermore, no differences were found for the yield components ears $/ \mathrm{m}^{2}$ and thousand grain weight. Inorganic $\mathrm{N}$ in the soil profile after harvest was generally below $40 \mathrm{~kg} \mathrm{~N} / \mathrm{ha}$ and did not differ between treatments. In the area where $\mathrm{N}$ was placed, mineral $\mathrm{N}$ was depleted during the vegetation period.

At the experimental sites a single $\mathrm{N}$ application in the period between tillering and stem elongation was sufficient to achieve high yield and quality of winter wheat without increased risk of nitrate leaching. This finding was independent of the method of application or the type of fertilizer.

\section{INTRODUCTION}

Increasing farm sizes with low manpower, increasing energy costs and ecological problems due to nitrogen (N) losses call for improved and simplified $\mathrm{N}$ fertilization. At present, management guidelines for cereals in Europe and the USA include recommendations for split application of mineral N. Splitting the fertilization into three or four doses is supposed to support specific yield components depending on the time of application and the corresponding stages of plant development (Hamid 1972; Alcoz et al. 1993). Furthermore, a split application is thought to avoid lodging and $\mathrm{N}$

* To whom all correspondence should be addressed. Email: Torsten. Mueller@uni-hohenheim.de losses by leaching (Gerwing et al. 1979; Kanwar et al. 1988; Varshney et al. 1993) because $\mathrm{N}$ application and $\mathrm{N}$ uptake are balanced both in time and amount.

However, other research indicates that weather conditions and total $\mathrm{N}$ supply are more important for yield and crude protein contents of cereals than splitting and the timing of applications (Fischbeck et al. 1990; Alcoz et al. 1993; Maidl et al. 1996). The effect of a split-N application on yield and quality of wheat is low if the total amount of $\mathrm{N}$ is sufficient (Müller et al. 1991) and the last $N$ application might not be taken up effectively by the plants, particularly under dry weather conditions in May and June, at the heading stage (Hartman \& Nyborg 1989). 
According to Fox et al. (1986) the timing of $\mathrm{N}$ application is an important factor for increasing $\mathrm{N}$ use efficiency (NUE). Nitrogen use efficiency is increased if $\mathrm{N}$ fertilization is restrained until tillering, but ample in the growth stages (GS) 30-39 (Zadoks et al. 1974; Maidl et al. 1998; Sticksel et al. 2000). It is thought that a limited $\mathrm{N}$ application before tillering avoids disproportionate side shoot production and excessive water consumption. Further, the risk of lodging as a result of rapid stem elongation is lower. However, the yield potential of modern winter wheat genotypes is mainly attributed to a higher partitioning of biomass to the grains, resulting in short stems (Austin et al. 1980) and thus reducing the risk of lodging compared to old genotypes.

Decades ago, many cultivars could be characterized as 'density types' or 'ear types' producing high yields either by a high density of ear-bearing stems (density types) or by a high number of spikelets/ear and a high thousand grain weight (ear type). Consequently, split- $\mathrm{N}$ fertilization was aimed at the promotion of single yield components depending on the variety. Modern cultivars, however, can be characterized as 'compensation types', where later-developing yield components (e.g. spikelets/ear) can compensate for limitations during the growth of yield components developed earlier (e.g. ear bearing stems $/ \mathrm{m}^{2}$ ), as it was decades ago. This is also visible in the German Descriptive Variety Lists, where the expression of yield components is characterized on a scale between 1 and 9 for each yield component. Extremes are very rare in the current list and all wheat varieties are characterized by medium values between 4 and 6 for at least two of the three yield components (Bundessortenamt 2012).

To simplify $\mathrm{N}$ fertilization, a reduction to one or two broadcast $\mathrm{N}$ applications may be an alternative to a traditional $\mathrm{N}$ application split into three or four doses. A single broadcast application would offer the advantage that only one pass over the field is needed and that no special application techniques are required, e.g. fertilizer placement.

An alternative to the split- $\mathrm{N}$ application is the placed ammonium $\left(\mathrm{NH}_{4}^{+}\right)$application, as a modification of the controlled uptake long-term ammonium nutrition (CULTAN)-fertilization described by Sommer (2000, 2005). The whole $\mathrm{N}$ amount is applied in one single dose in spring, either directly injected into the soil or placed on the soil surface as depots or depot bands with high $\mathrm{NH}_{4}^{+}$concentration. Typically, this application is done much later than the traditional first application. This forces the plant to invest in root growth, facilitating nutrient and water uptake at a later stage. As an alternative, a part of the $\mathrm{NH}_{4}^{+}$may be replaced by urea, which is assumed to mineralize quickly to $\mathrm{NH}_{4}^{+}$. A diffusion zone develops concentrically around the depot, from which $\mathrm{NH}_{4}^{+}$and - after nitrification (and following diffusion and mass flow) - nitrate $\left(\mathrm{NO}_{3}^{-}\right)$can be taken up by plant roots (Schittenhelm \& MengeHartmann 2006; Menge-Hartmann \& Schittenhelm 2008). A high share of $\mathrm{NH}_{4}^{+}$uptake in contrast to the usually dominating $\mathrm{NO}_{3}^{-}$uptake may affect the distribution of assimilates within the plant, the phytohormone production and the intensity of growth of different organs (Sommer \& Scherer 2009). An injection of $N$ fertilizer results in lower gaseous $\mathrm{N}$ losses and provides an appropriate amount of $\mathrm{N}$ under dry conditions, particularly under a soil surface mulch layer in conservation tillage or no-till systems (Liu et al. 2006).

To obtain direct and bilateral transfer of knowledge and methodologies, the current investigation was conducted as a joint approach between farmers, local extension service and the university. To address farmers' needs, the main object was to investigate $\mathrm{N}$ fertilizing strategies in winter wheat under normal farming practice on farmers' fields. This is in contrast to most of the studies mentioned above, which were based on on-station experiments. Studies on farmers' fields are termed 'on-farm experiments' and aim to obtain practice-orientated results.

Soil nutrients, plot size, equipment, etc. are the main differences between fields within farms and between farms, causing great variations. Hence, for statistical analysis of on-farm experiments, the same requirements as for on-station experiments need to be fulfilled: randomization, replication, blocking (Piepho et al. 2011).

Thus, the aim of the present study was to investigate strategies for a simplified $\mathrm{N}$ fertilization in winter wheat under practice-related conditions on farmers' fields. Besides the traditional three-split applications the alternative strategies tested were one or two applications of broadcast $\mathrm{N}$ and a single placed $\mathrm{NH}_{4}^{+}$ fertilization. Following the idea of Sommer (2000, 2005), the single application and the first application of the two times split application should be late, at the end of tillering/beginning of shooting (GS 27-32), when the second application was done for the three times split application. 
The following hypotheses, related to the site conditions of the current investigation, were tested: (1) a reduction in the number of $\mathrm{N}$ broadcast applications to winter wheat with a late (first) $\mathrm{N}$ application does not affect yield and quality; (2) a reduction of the number of $\mathrm{N}$ broadcast applications to winter wheat with a late (first) $\mathrm{N}$ application does not increase the risk for $\mathrm{NO}_{3}^{-}$leaching losses; and (3) compared to a single broadcast application of $\mathrm{N}$, a single placed depot application of $\mathrm{NH}_{4}^{+}$- and ureadominated fertilizers leads to higher yields and to a reduced risk for $\mathrm{NO}_{3}^{-}$leaching.

\section{MATERIALS AND METHODS}

\section{Study sites}

The investigation was performed over 4 years in two rural districts, Tübingen $\left(48^{\circ} 24^{\prime}-48^{\circ} 28^{\prime} \mathrm{N}, 8^{\circ} 50^{\prime}-\right.$ $\left.9^{\circ} 05^{\prime} \mathrm{E}\right)$ and Biberach $\left(48^{\circ} 01^{\prime}-48^{\circ} 08^{\prime} \mathrm{N}, 9^{\circ} 26^{\prime}-9^{\circ} 46^{\prime} \mathrm{E}\right)$, Baden-Württemberg, South-West Germany. Four agricultural farms in 2007, six in 2008, 11 in 2009 and 11 in 2010 took part with one or more fields in the intended fertilization experiments. Each field included three to five plots, and, thus, the same number of fertilization treatments. The size of one plot was c. $100 \mathrm{~m}$ long $\times$ c. $12-16 \mathrm{~m}$ wide, depending on the working width of the farm machinery used and the individual field conditions.

The study sites varied slightly in terms of climatic conditions and altitude above sea level. The experimental fields are characterized as follows: (1) Tübingen: $450 \mathrm{~m}$ a.s.l.; average annual temperature: $9-10^{\circ} \mathrm{C}$; soil textures: silty loam and clayey loam; (2) Biberach: $550 \mathrm{~m}$ a.s.l.; average annual temperature: $8-9^{\circ} \mathrm{C}$; soil textures: silty loam and sandy loam. Soil types on 12 farms in both areas were Haplic Luvisols, on three farms Gleyic Luvisols and on two farms Calcic Cambisols. The average annual precipitation (1960-1990) was similar in both rural districts and accounted for 700 (Tübingen) $-800 \mathrm{~mm}$ (Biberach). The long-term average climatic water balance (1960-1990) for the hydrological summer half-year was $0-100 \mathrm{~mm}$ in Tübingen and $100-200 \mathrm{~mm}$ in Biberach (Wasser- und Bodenatlas BadenWürttemberg 2012). Since average temperatures and thus evaporation increased in the last two decades and dry springs appeared more often (see the later section on weather conditions), so the risk of nitrate leaching during vegetation period from loamy soils was assumed to be low.

\section{Farmer participatory approach}

The experimental setup and fertilization treatments were developed jointly with participating farmers and local extension services, during workshops prior to the start of the experiments. Data from the first experimental year were presented to the farmers as a pre-requisite for modifications in the experimental design of the following years. The final results were presented to the farmers and discussed together after each year.

More than half of the participating farms had livestock. All farms practised conservation soil tillage (no soil inversion by mouldboard ploughing) and none of them used plant growth regulators to avoid lodging. According to the recommendations of the official extension services, available plant nutrients [phosphorus $(\mathrm{P})$, potassium $(\mathrm{K})$, magnesium $(\mathrm{Mg})$ and sulphur (S)] in the soil were at a medium level and thus not expected to limit plant production.

Winter high-protein wheat cultivars chosen by farmers in the 4 years are characterized mainly as compensation types, some with slight tendencies towards plant density or ear types. The preceding crops were oilseed rape, sugar beet, potatoes, pea or winter wheat and, on one field only, strawberries.

\section{Fertilizer treatments}

Fertilizer types, application techniques, number of applications, application times and number of replications used in the field experiments are shown in Table 1. At each field, selected treatments were arranged, representing one (incomplete) block (see statistics below). Control plots (small zero fertilization windows) without $\mathrm{N}$ fertilization were partially installed, but are not included in the statistical analysis.

The amount of fertilizer $\mathrm{N}$ applied on each field was calculated in line with recommendations of the official extension service. This takes into account the expected $\mathrm{N}$ demand considering the expected grain yield and crude protein content. The inorganic $\mathrm{N}$ already available in soil, sampled in early spring in the 0-90 cm soil layer, was subtracted from the expected $\mathrm{N}$ demand, as well as the assumed $\mathrm{N}$ delivery from soil during the cultivation period, long-term manure application and plant residues of pre-crops and intermediate crops (Düngeverordnung 2009). The fertilizer $\mathrm{N}$ amount for an individual experimental field was always the same for all treatments. The fertilizer $\mathrm{N}$ amount was usually in the range 


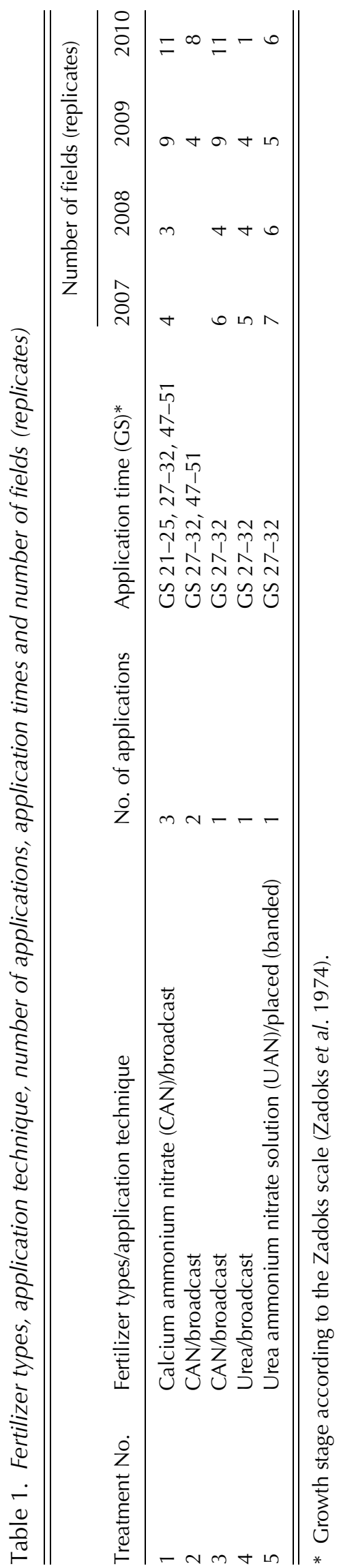

$200 \pm 20 \mathrm{~kg} \mathrm{~N} / \mathrm{ha}$ and only exceptionally lower or higher. As a result, the total $\mathrm{N}$-supply was in the range of $180-260 \mathrm{~kg} \mathrm{~N} / \mathrm{ha}$.

Broadcast fertilizer application was achieved using farmers' broadcast or pneumatic spreaders. Broadcast spreaders were used half-sided so that a single plot was fertilized by an exact overlap of two crossings. Placed surface application (band application) of urea ammonium nitrate solutions was carried out using pesticide sprayers in combination with tracking hoses.

\section{Weather conditions}

Climatic conditions in South-West Germany have changed in recent decades, moving towards higher average annual temperatures and more extreme weather situations including dry conditions in spring and more thunderstorms with heavy rainfall in summer. The average annual temperature in the area of the field experiments at Tübingen increased from $8 \cdot 8^{\circ} \mathrm{C}(1961-1990)$ to $9.9^{\circ} \mathrm{C}(1991-2010)$ (Institute of Physics and Meteorology, University of Hohenheim). Therefore, it is worth comparing the weather conditions during the growing season of winter wheat with the mean weather data of the last two decades (1991-2010) (Table 2).

Weather conditions during the cultivation of winter wheat in the 4 years of field experiments were characterized by extremes. In 3 out of the 4 years $(2007,2009,2010)$, April was dry and relatively warm, followed by high precipitation in May in 2007 and 2009. There is a trend towards a dry spring in SouthWest Germany, whereas precipitation as well as temperature in the remaining months was highly variable compared with the average of 1991-2010.

Data collection

Plant analyses

Harvesting of the individual treatments was performed by combine harvesters with integrated grain yield recording. In addition, in 2007 and 2008 yield components (spikes $/ \mathrm{m}^{2}$, grains/ear, thousand grain weight) were determined by sampling plants in five (2007) or three sampling points (2008) per treatment in each field, each of which had an area of $0.28 \mathrm{~m}^{2}$.

Plant samples were oven dried $\left(60^{\circ} \mathrm{C}\right)$ to constant weight and nitrogen concentrations were analysed with a $C / N$ auto-analyser ('Elementar', model 'vario Max $\mathrm{CN}^{\prime}$, Hanau, Germany). Crude protein content 
Table 2. Weather conditions 2007-2010 during the main growing season and deviation from mean values of the last two decades 1991-2010. (Institute of Physics and Meteorology, University of Hohenheim)

\begin{tabular}{|c|c|c|c|c|c|}
\hline Year & Month & $\begin{array}{l}\text { Temperature } \\
\left({ }^{\circ} \mathrm{C}\right)\end{array}$ & $\begin{array}{l}\text { Deviation from } \\
\text { long-term } \\
\text { average }\left({ }^{\circ} \mathrm{C}\right)\end{array}$ & $\begin{array}{l}\text { Precipitation } \\
(\mathrm{mm})\end{array}$ & $\begin{array}{l}\text { Deviation from } \\
\text { long-term } \\
\text { average }(\mathrm{mm})\end{array}$ \\
\hline \multirow[t]{5}{*}{2007} & March & $6 \cdot 3$ & $+0 \cdot 6$ & $57 \cdot 2$ & +2.9 \\
\hline & April & $13 \cdot 9$ & $+4 \cdot 2$ & 0.5 & $-40 \cdot 8$ \\
\hline & May & $15 \cdot 5$ & $+1 \cdot 4$ & $116 \cdot 8$ & $+33 \cdot 5$ \\
\hline & June & $18 \cdot 0$ & $+0 \cdot 8$ & $131 \cdot 3$ & $+46 \cdot 6$ \\
\hline & July & $18 \cdot 0$ & $-1 \cdot 0$ & $85 \cdot 4$ & $-5 \cdot 0$ \\
\hline \multirow[t]{5}{*}{2008} & March & $5 \cdot 1$ & $-0 \cdot 6$ & $53 \cdot 2$ & $-1 \cdot 1$ \\
\hline & April & $8 \cdot 4$ & $-1 \cdot 3$ & $68 \cdot 0$ & $+26 \cdot 7$ \\
\hline & May & $16 \cdot 0$ & $+1 \cdot 9$ & $96 \cdot 4$ & $+13 \cdot 1$ \\
\hline & June & $18 \cdot 0$ & $+0 \cdot 8$ & $93 \cdot 9$ & $+9 \cdot 2$ \\
\hline & July & $18 \cdot 8$ & $-0 \cdot 3$ & $64 \cdot 5$ & $-25 \cdot 9$ \\
\hline \multirow[t]{5}{*}{2009} & March & $4 \cdot 7$ & $-1 \cdot 0$ & $82 \cdot 6$ & $+28 \cdot 3$ \\
\hline & April & $12 \cdot 6$ & $+2 \cdot 9$ & $17 \cdot 7$ & $-23 \cdot 6$ \\
\hline & May & $15 \cdot 3$ & $+1 \cdot 2$ & $129 \cdot 1$ & $+45 \cdot 8$ \\
\hline & June & $16 \cdot 5$ & $-0 \cdot 7$ & $76 \cdot 5$ & $-8 \cdot 2$ \\
\hline & July & $18 \cdot 8$ & $-0 \cdot 3$ & $140 \cdot 3$ & $+49 \cdot 9$ \\
\hline \multirow[t]{5}{*}{2010} & March & $4 \cdot 9$ & $-0 \cdot 8$ & $28 \cdot 0$ & $-26 \cdot 3$ \\
\hline & April & $10 \cdot 1$ & $+0 \cdot 4$ & $7 \cdot 4$ & $-33 \cdot 9$ \\
\hline & May & $11 \cdot 4$ & $-2 \cdot 7$ & $83 \cdot 8$ & +0.5 \\
\hline & June & $17 \cdot 5$ & $+0 \cdot 3$ & $70 \cdot 4$ & $-14 \cdot 3$ \\
\hline & July & $20 \cdot 8$ & $+1 \cdot 7$ & $99 \cdot 0$ & $+8 \cdot 6$ \\
\hline
\end{tabular}

was determined by multiplying $\mathrm{N}$ concentration by a factor of $5 \cdot 7$ (Teller 1932).

\section{Soil analyses}

Soil samples for determination of inorganic $\mathrm{N}\left(\mathrm{NH}_{4}^{+}\right.$ and $\mathrm{NO}_{3}^{-}$) were taken from each field in spring before $N$ fertilization $(0-90 \mathrm{~cm})$ and from each plot after harvest $(0-90 \mathrm{~cm})$ (VDLUFA 2007). Furthermore, soil samples $(0-30 \mathrm{~cm})$ were taken from the centre of an application band of urea ammonium nitrate solution during the vegetation period to determine the concentration of $\mathrm{NO}_{3}^{-}$and $\mathrm{NH}_{4}^{+}$in the fertilizer band. Placement bands were labelled in the field immediately after application using plastic sticks to ensure correct soil sampling. Soil samples of each plot and at each time were taken in triplicate. Samples were analysed for inorganic $\mathrm{N}$ with a continuous flow analyser (AutoAnalyzer 3, Bran + Luebbe/SEAL Analytical Norderstedt, Germany).

\section{Statistics}

The current investigation of $\mathrm{N}$ fertilizing strategies in winter wheat was conducted under normal farming practices. A fertilizing strategy (treatment) was defined as a combination of a fertilizer treatment $(F)$ and an application frequency $(A)$. Farmers were allowed to test additional individual fertilizing strategies as long as they also tested some of the fertilizing strategies of interest to the scientific partners (co-treatments). On every field, thus, core treatments appeared together with individual treatments tested on some fields only. The most obvious design for this purpose is the incomplete block design, defining each field as an incomplete block. The different treatments tested on that field are randomized (Piepho et al. 2011). A pre-requisite for this design is that each block contains at least one treatment which occurs in at least one other block, so that all blocks are connected. The values of yield and crude protein contents were collected in years 2007-2010 on all fields and an ANOVA could be conducted. Soil mineral $N$ and yield components, such as ears $/ \mathrm{m}^{2}$, grains/ear and thousand grain weight, were collected in the first 2 years but on some fields only, resulting in a poor database. Therefore, only descriptive statistics were used.

On-farm field trial data from 4 years were analysed separately for each year and jointly for all years. 
Table 3. Overview of year $\times$ farm $\times$ field $\times$ treatment combinations available in the dataset. Crosses identify the available combinations

\begin{tabular}{|c|c|c|c|c|c|c|c|}
\hline \multirow[b]{2}{*}{ Farm } & \multirow[b]{2}{*}{ Field } & \multirow[b]{2}{*}{ Year } & \multicolumn{3}{|c|}{ CAN } & \multirow{2}{*}{$\begin{array}{l}\text { Urea } \\
1 \text { Appl. }\end{array}$} & \multirow{2}{*}{$\begin{array}{l}\text { UAN } \\
1 \text { Appl }\end{array}$} \\
\hline & & & 1 Appl.* & 2 Appl. & 3 Appl. & & \\
\hline 1 & 1 & 2010 & $x$ & $x$ & $x$ & & $x$ \\
\hline 2 & 2 & 2010 & $x$ & & $x$ & & $x$ \\
\hline 3 & 3 & 2007 & & & $x$ & $x$ & $x$ \\
\hline 3 & 4 & 2008 & & & & $x$ & $x$ \\
\hline 3 & 5 & 2010 & $x$ & $x$ & $x$ & & $x$ \\
\hline 4 & 6 & 2010 & $x$ & $x$ & $x$ & & \\
\hline 5 & 7 & 2010 & $x$ & $x$ & $x$ & & \\
\hline 6 & 8 & 2008 & $x$ & & $x$ & $x$ & \\
\hline 6 & 9 & 2009 & $x$ & & $x$ & $x$ & $x$ \\
\hline 6 & 10 & 2010 & $x$ & & $x$ & $x$ & $x$ \\
\hline 7 & 11 & 2009 & $x$ & $x$ & $x$ & & \\
\hline 7 & 12 & 2009 & $x$ & $x$ & $x$ & & \\
\hline 7 & 13 & 2010 & $x$ & $x$ & $x$ & & \\
\hline 8 & 14 & 2009 & $x$ & & $x$ & & $x$ \\
\hline 8 & 15 & 2010 & $x$ & & $x$ & & \\
\hline 9 & 16 & 2007 & & & $x$ & $x$ & $x$ \\
\hline 9 & 17 & 2007 & & & & $x$ & $x$ \\
\hline 9 & 18 & 2010 & $x$ & $x$ & $x$ & & $x$ \\
\hline 10 & 19 & 2008 & & & & $x$ & $x$ \\
\hline 10 & 20 & 2009 & $x$ & & $x$ & $x$ & $x$ \\
\hline 11 & 21 & 2009 & $x$ & $x$ & $x$ & & \\
\hline 12 & 22 & 2007 & $x$ & & $x$ & $x$ & $x$ \\
\hline 12 & 23 & 2007 & $x$ & & $x$ & $x$ & $x$ \\
\hline 12 & 24 & 2009 & $x$ & & $x$ & $x$ & \\
\hline 13 & 25 & 2007 & $x$ & & $x$ & $x$ & $x$ \\
\hline 13 & 26 & 2007 & $x$ & & $x$ & $x$ & $x$ \\
\hline 13 & 27 & 2008 & $x$ & & $x$ & & $x$ \\
\hline 13 & 28 & 2009 & $x$ & & $x$ & & \\
\hline 14 & 29 & 2009 & $x$ & & $x$ & $x$ & \\
\hline 14 & 30 & 2010 & $x$ & $x$ & $x$ & & \\
\hline 15 & 31 & 2009 & & & & & $x$ \\
\hline 16 & 32 & 2009 & & & & & $x$ \\
\hline 17 & 33 & 2008 & & & $x+$ & & $x+$ \\
\hline 18 & 34 & 2008 & & & $x$ & & $x$ \\
\hline 18 & 35 & 2010 & $x$ & $x$ & $x$ & & $x$ \\
\hline 19 & 36 & 2008 & & & & $x$ & $x$ \\
\hline
\end{tabular}

* Application.

+ Only data for crude protein were available for farm 17, field 11 .

The yield data were collected from 33 fields at 15 farms and the crude protein data from 34 fields at 16 farms. Each field on the farms was used only once over the 4-year period. The trials comprised nine fertilizer treatments $(F)$ and three application frequencies $(A)$. Among the possible treatments formed from factors $F$ and $A$, up to 14 were tested. Among these 14 combinations, the main focus were five combinations (Table 1), i.e. on calcium ammonium nitrate (CAN) applied once, twice or three times as well as on urea and urea ammonium nitrate solution (UAN) applied once.

For yield and crude protein, all available combinations were used for statistical analyses. The number of treatments tested per field varied between two and six. Due to the design of the on-farm trials, the data were highly unbalanced (Table 3 ).

The mixed model for a single year was:

$y=\mu+F+F . A:$ FIELD $+e$ 
Table 4. F-tests (fixed effects) and variance component estimates (random effects) for yield and crude protein for analyses across years and per year. For a single year there is no $\mathrm{Y} \times$ Field effect but only a FIELD effect, but these effects are reported in a single column

\begin{tabular}{|c|c|c|c|c|c|c|c|c|c|}
\hline & \multicolumn{4}{|c|}{ Fixed effects ( $F$-tests) } & \multirow{2}{*}{\multicolumn{5}{|c|}{ Random effects (variance components) }} \\
\hline & \multirow{2}{*}{\multicolumn{2}{|c|}{ Fertilizer }} & \multirow{2}{*}{\multicolumn{2}{|c|}{$\begin{array}{c}\text { Fertilizer } \\
\text { application } \\
\text { frequency }\end{array}$}} & & & & & \\
\hline & & & & & \multirow[b]{2}{*}{ Year } & \multirow{2}{*}{$\begin{array}{l}\text { Y.FIELD/ } \\
\text { FIELD }\end{array}$} & \multirow[b]{2}{*}{ F.Y } & \multirow[b]{2}{*}{ F.A.Y } & \multirow{2}{*}{$\begin{array}{l}\text { Error } \\
\text { term* }\end{array}$} \\
\hline & $F$ value & $P$ value & $F$ value & $P$ value & & & & & \\
\hline Yield 2007-2010 & $0 \cdot 89$ & NS & $0 \cdot 78$ & NS & $100 \cdot 76$ & $132 \cdot 45$ & 0 & 0 & $9 \cdot 26$ \\
\hline Yield 2007 & $0 \cdot 03$ & NS & $0 \cdot 37$ & NS & - & $78 \cdot 86$ & - & - & $13 \cdot 44$ \\
\hline Yield 2008 & $1 \cdot 08$ & $<0 \cdot 05$ & $0 \cdot 62$ & NS & - & $54 \cdot 38$ & - & - & $13 \cdot 54$ \\
\hline Yield 2009 & $0 \cdot 10$ & NS & $0 \cdot 80$ & NS & - & $225 \cdot 60$ & - & - & $8 \cdot 91$ \\
\hline Yield 2010 & $0 \cdot 87$ & NS & 0.63 & NS & - & $86 \cdot 03$ & - & - & $12 \cdot 73$ \\
\hline Crude protein 2007-2010 & $1 \cdot 58$ & NS & $2 \cdot 58$ & NS & $1 \cdot 25$ & 0.99 & $0 \cdot 009$ & $0 \cdot 06$ & $0 \cdot 29$ \\
\hline Crude protein 2007 & $8 \cdot 72$ & $<0 \cdot 01$ & $2 \cdot 22$ & NS & - & $0 \cdot 71$ & - & - & $0 \cdot 17$ \\
\hline Crude protein 2008 & $0 \cdot 39$ & NS & $6 \cdot 14$ & $<0.05$ & - & $1 \cdot 06$ & - & - & $0 \cdot 33$ \\
\hline Crude protein 2009 & $3 \cdot 57$ & NS & $3 \cdot 21$ & NS & - & $0 \cdot 94$ & - & - & $0 \cdot 29$ \\
\hline Crude protein 2010 & $2 \cdot 22$ & NS & $5 \cdot 19$ & $<0 \cdot 05$ & - & $1 \cdot 09$ & - & - & $0 \cdot 32$ \\
\hline
\end{tabular}

* Residual variance of the model.

where $y$ is the dependent variable yield or crude protein; $\mu$ the overall mean; $F$ is the main effect of fertilizer; F.A is the nested effect of application frequency $(A)$ within fertilizer; FIELD is the main effect for field and e is a residual error. The colon separates fixed effects, listed first, from random effects. The mixed model across years was:

$y=\mu+F+F . A: Y+Y . F I E L D+F . Y+F . A . Y+e$

where fixed effects are as defined for Eqn (1) and random effects now include random interaction effects with year $(Y)$ as well as a field effect nested within years (Y.FIELD). Wald-type F-tests of fixed effects were performed, adjusting the denominator D.F. using the Kenward-Roger method. The Tukey test, which controls the family-wise type I error rate, was used for mean comparisons among the five treatments. The adjusted means shown in figures are those from the model across years containing all combinations of fertilizer and application frequency. Due to the unbalanced nature of the data, letter displays were generated using the method of Piepho (2012).

\section{RESULTS}

Wald-type $F$-tests for fixed effects as well as variance component estimates for random effects are reported in Table 4. The adjusted means are shown in Table 5.

\section{Grain yield}

The grain yields of the different fertilization treatments including the $\mathrm{N}$ fertilizer types CAN, urea and UAN solution, the number of applications $(3 \times \mathrm{CAN}$, $1 \times \mathrm{CAN}, 1 \times$ urea, $1 \times \mathrm{UAN}$ ) and the different application techniques (CAN and urea broadcast; UAN placed) were not significantly different, either over the period of 4 years (Fig. 1) or in any of the 4 years (data not shown). Yields of the control plots (if existing) were typically between 0.60 and 0.65 of the other treatments. However, due to different weather conditions, the mean yield varied highly between the four years. In 2007, 2008, 2009 and 2010 the average grain yield levels of the core treatments were $8 \cdot 5,9 \cdot 4,7 \cdot 0$ and $7 \cdot 3 \mathrm{tDM} / \mathrm{ha}$, respectively.

Although no growth regulators were applied by farmers, no lodging occurred in any of the 4 years, not even after a single application. In some fields, winter wheat plants in the treatments with a reduced number of applications showed clear $\mathrm{N}$ deficiency symptoms at the end of tillering. However, c. 3 weeks after the late (first) application, deficiency symptoms disappeared and visual differences between the fertilization treatments could no longer be observed. 
Table 5. Adjusted means, mean grouping by letters ( \pm S.E.M.) for the five fertilizer treatments for yield and crude protein for analyses across years and per year

\begin{tabular}{|c|c|c|c|c|c|c|c|}
\hline & \multirow[b]{2}{*}{ Fertilizer } & \multirow{2}{*}{$\begin{array}{l}\text { No. of } \\
\text { Appl. }\end{array}$} & \multicolumn{5}{|c|}{ Mean } \\
\hline & & & 2007-2010 & 2007 & 2008 & 2009 & 2010 \\
\hline \multirow[t]{5}{*}{ Yield } & CAN & 1 & $79 \cdot 2 \pm 5 \cdot 47$ & $85 \cdot 2 \pm 3 \cdot 89$ & $92 \cdot 8 \pm 4 \cdot 35$ & $68 \cdot 6 \pm 4 \cdot 67$ & $71 \cdot 6 \pm 3 \cdot 00$ \\
\hline & CAN & 2 & $79 \cdot 5 \pm 5 \cdot 5$ & - & - & $67 \cdot 7 \pm 4 \cdot 99$ & $72 \cdot 7 \pm 3 \cdot 10$ \\
\hline & CAN & 3 & $80 \cdot 3 \pm 5 \cdot 4$ & $83 \cdot 7 \pm 3 \cdot 70$ & $95 \cdot 6 \pm 3 \cdot 93 a$ & $70 \cdot 0 \pm 4 \cdot 67$ & $73 \cdot 3 \pm 3 \cdot 00$ \\
\hline & Urea & 1 & $79 \cdot 6 \pm 5 \cdot 5$ & $84 \cdot 9 \pm 3 \cdot 63$ & $91 \cdot 6 \pm 3 \cdot 64 a$ & $69 \cdot 6 \pm 4 \cdot 84$ & $68 \cdot 3 \pm 4 \cdot 95$ \\
\hline & UAN & 1 & $80 \cdot 8 \pm 5 \cdot 48$ & $84 \cdot 9 \pm 3 \cdot 63$ & $95 \cdot 5 \pm 3 \cdot 46$ & $69 \cdot 3 \pm 4 \cdot 81$ & $73 \cdot 7 \pm 3 \cdot 21$ \\
\hline \multirow[t]{5}{*}{ Crude Protein } & CAN & 1 & $13 \cdot 0 \pm 0 \cdot 62 a$ & $14 \cdot 2 \pm 0 \cdot 39 a$ & $11 \cdot 1 \pm 0 \cdot 63 a$ & $12 \cdot 5 \pm 0 \cdot 35 \mathrm{ab}$ & $14 \cdot 1 \pm 0 \cdot 36 a$ \\
\hline & CAN & 2 & $13 \cdot 3 \pm 0 \cdot 66 a$ & - & - & $12 \cdot 9 \pm 0 \cdot 47 a b$ & $14 \cdot 5 \pm 0 \cdot 38 a b$ \\
\hline & CAN & 3 & $13 \cdot 6 \pm 0 \cdot 61 a$ & $13 \cdot 8 \pm 0 \cdot 36 a b$ & $12 \cdot 5 \pm 0 \cdot 51 \mathrm{a}$ & $13 \cdot 2 \pm 0 \cdot 35 a$ & $14 \cdot 9 \pm 0 \cdot 36 b$ \\
\hline & Urea & 1 & $12 \cdot 9 \pm 0 \cdot 62 a$ & $13 \cdot 1 \pm 0 \cdot 35 b$ & $11 \cdot 8 \pm 0 \cdot 51 \mathrm{a}$ & $11 \cdot 9 \pm 0 \cdot 42$ & $15 \cdot 7 \pm 0 \cdot 72 b$ \\
\hline & UAN & 1 & $13 \cdot 3 \pm 0 \cdot 61 a$ & $13 \cdot 8 \pm 0 \cdot 35 a$ & $12 \cdot 1 \pm 0 \cdot 46 a$ & $12 \cdot 6 \pm 0 \cdot 41 b$ & $14 \cdot 9 \pm 0 \cdot 40 b$ \\
\hline
\end{tabular}

* Means within a column and trait showing a common letter are not significantly different according to a Tukey test. No significant differences were found for yield.

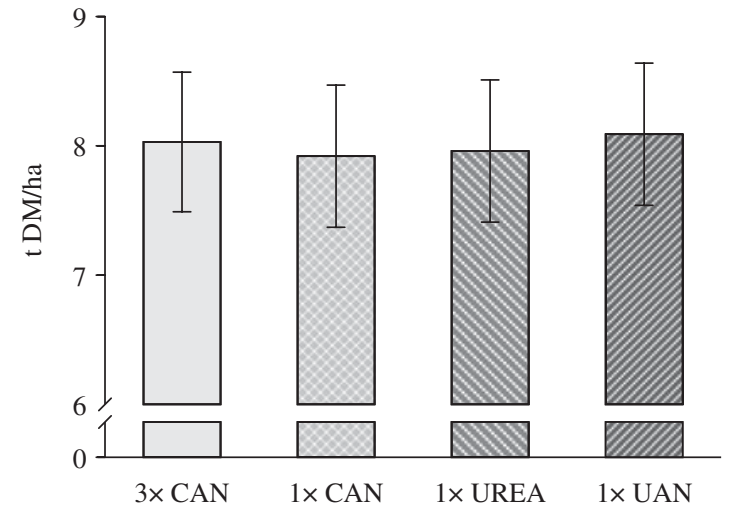

Fig. 1. Mean grain yield of the fertilization treatments calcium ammonium nitrate $(\mathrm{CAN})$, urea and urea ammonium nitrate solution (UAN) 2007-2010. Bars show S.E. of the means.

The two-time split application of CAN was included in 2009 and 2010 only. In both years, there was no difference in grain yield between this treatment and conventional $\mathrm{N}$ fertilization applied three times (Fig. 2).

\section{Crude protein}

There were no significant differences in crude protein contents between the treatments (conventional split application of CAN, single broadcast application of CAN or urea and single placed application of UAN solution) over a period of 4 years (Fig. 3). No significant differences were observed in the individual years either, except in 2010 which had relatively high crude protein contents in all treatments. Here, the crude

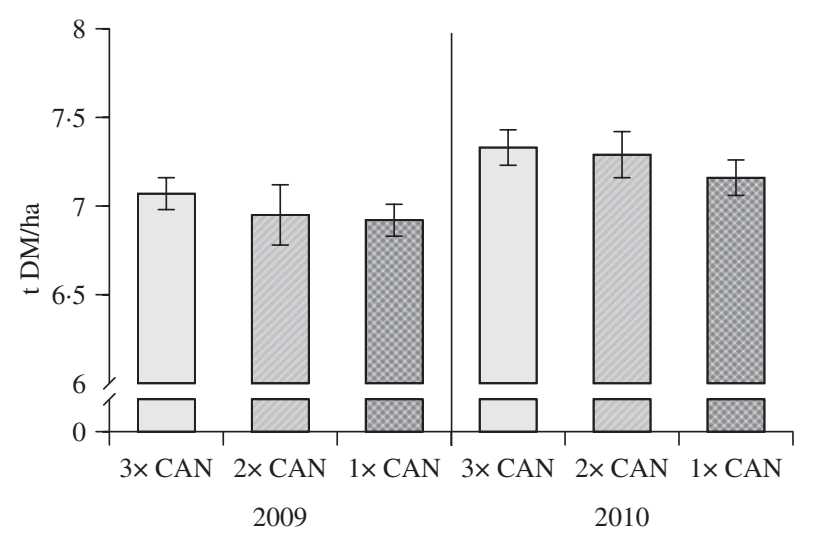

Fig. 2. Grain yield of the split $(3 \times, 2 \times)$ and single $(1 \times)$ applications of calcium ammonium nitrate (CAN) in 2009 and 2010. Bars show S.E. of the means.

protein of the single application of CAN was significantly lower $(P<0 \cdot 05)$ than that of the conventional split application (Fig. 4). The mean crude protein levels in 2007, 2008, 2009 and 2010 were 13.7, 11.9, 12.4 and $14.9 \%$, respectively. In the year with highest grain yield (2008:9.4tDM/ha), crude protein was lowest.

Yield components were measured in the first 2 years of the field experiments. In 2008, spikes averaged 587 ears $/ \mathrm{m}^{2}$ with no difference between treatments. In 2007 a mean value of $39 \cdot 7$ grains/ear was measured, showing higher numbers for the single broadcast application of urea and the single placed application of UAN solution as compared to the conventional split application (data not shown). In contrast, in 2008 no differences appeared between these treatments. 


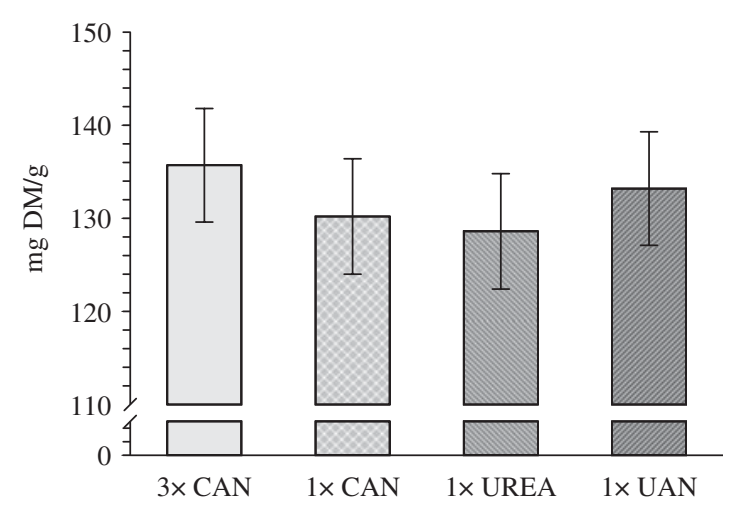

Fig. 3. Mean crude protein content of the fertilization treatments three times $(3 \times)$ and single application $(1 \times)$ of calcium ammonium nitrate (CAN), and single application of urea and urea ammonium nitrate solution (UAN) 2007-2010. Bars show S.E. of the means.

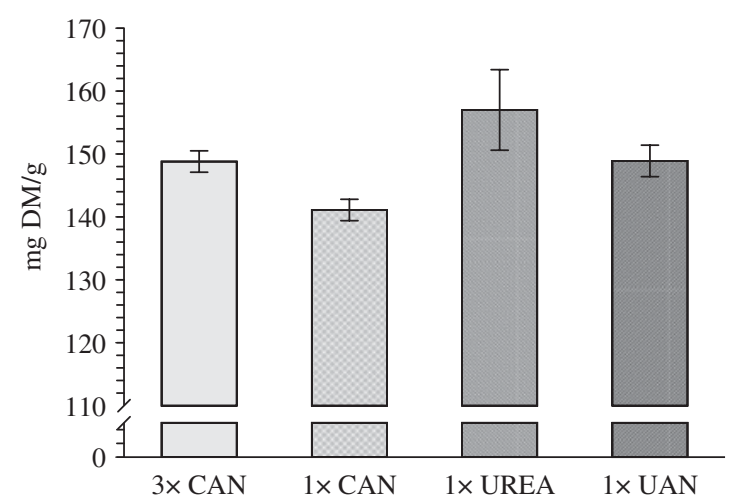

Fig. 4. Crude protein content of the fertilization treatments three times $(3 \times)$ and single application $(1 \times)$ of calcium ammonium nitrate $(\mathrm{CAN})$, and single application of urea and urea ammonium nitrate solution (UAN) in 2010. Bars show S.E. of the means.

The thousand grain weight did not differ between any of the treatments in 2008. An average of $46 \mathrm{~g}$ dry weight per thousand grains was measured.

\section{Soil mineral $\mathrm{N}$}

The inorganic $\mathrm{N}$ after harvest in 2007 and 2008 accounted for $<20 \mathrm{~kg} \mathrm{~N} / \mathrm{ha}$ in the top soil $(0-30 \mathrm{~cm})$ and $<10 \mathrm{~kg} \mathrm{~N} / \mathrm{ha}$ in the $30-60 \mathrm{~cm}$ layer, and showed no significant differences between the fertilization treatments in either year (data not shown). In 2009 and 2010, splitting of CAN had no effect on the content of residual inorganic $\mathrm{N}$ in the soil profile (Fig. 5).

The soil samples from the labelled placement bands 10 days after the application of UAN at GS 30-32

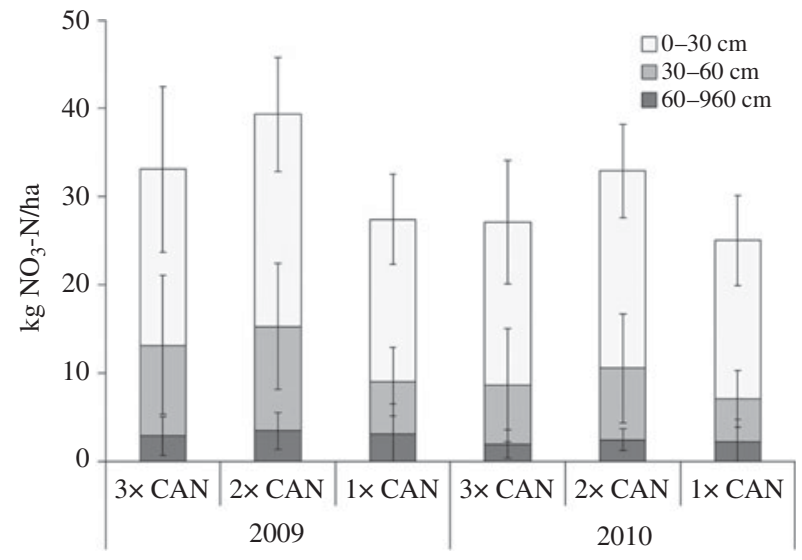

Fig. 5. $\mathrm{NO}_{3}^{-}-\mathrm{N}$ after harvest in the soil layers $0-30,30-60$ and $60-90 \mathrm{~cm}$ of the split $(3 \times, 2 \times)$ and single $(1 \times)$ applications of calcium ammonium nitrate (CAN) in 2009 and 2010. Bars show S.D.

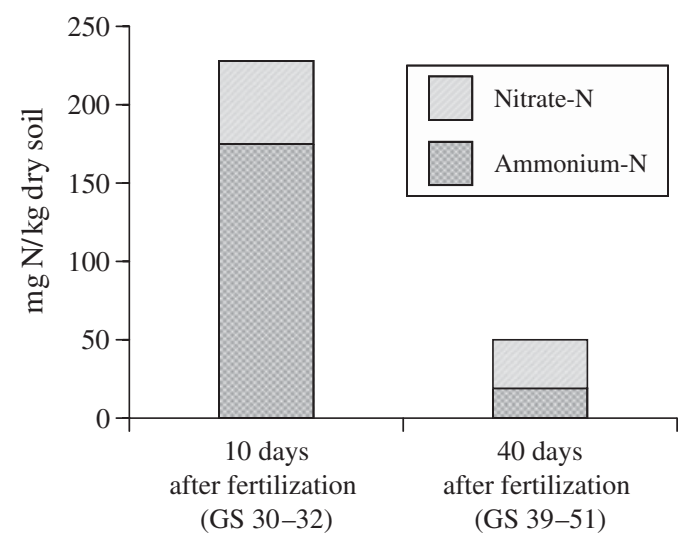

Fig. 6. $\mathrm{NH}_{4}^{+}-\mathrm{N}$ and $\mathrm{NO}_{3}^{-}-\mathrm{N}$ in the placement band of urea ammonium nitrate solution (UAN) 10 and 40 days after fertilization in 2008.

showed a concentration of $230 \mathrm{mg}$ inorganic $\mathrm{N} / \mathrm{kg}$ soil with a proportion of $0.77 \mathrm{NH}_{4}^{+}-\mathrm{N}$ in the year 2008 (Fig. 6). Forty days after the placed application, mineral $\mathrm{N}$ in the placement band was reduced to $50 \mathrm{mg} \mathrm{N} / \mathrm{kg}$ soil with a proportion of $0.62 \mathrm{NO}_{3}^{-}-\mathrm{N}$. The soil samples $(0-30 \mathrm{~cm})$ from the soil between the placements showed maximum soil values reaching $5 \mathrm{mg} \mathrm{NH}_{4}^{+} \mathrm{N}$ and $20 \mathrm{mg} \mathrm{NO}_{3}^{-}-\mathrm{N} / \mathrm{kg}$ soil during the vegetation period (data not shown). After harvest, the placed area was almost depleted and not significantly different to the other broadcast applied treatments.

\section{DISCUSSION}

Grain yields between the treatments were not significantly different in any of the 4 years. It seems that a single $\mathrm{N}$ application between advanced tillering 
and beginning of stem elongation, either broadcast or placed, is sufficient to produce high yields on the current experimental sites. Furthermore, there were no significant differences between the fertilizer types CAN, urea and UAN. Consequently, there were no differences in fertilizer $\mathrm{N}$ use efficiency if comparing application techniques or fertilizer types. This finding can be attributed to the properties of the experimental sites. Luvisols with loamy texture are characterized by high fertility and high $\mathrm{N}$ mineralization potential, enabling winter wheat plants to compensate temporal periods of $\mathrm{N}$ deficiency caused by insufficient fertilizer $\mathrm{N}$ supply.

Among the other factors affecting yield, weather is the most important variable followed by the total amount of applied N, N application timings and technique (Fischbeck et al. 1990; Alcoz et al. 1993; Maidl et al. 1996). In 3 of the 4 years of the field experiments $(2007,2009,2010)$ April was dry and relatively warm. Therefore, it was thought that $\mathrm{N}$ fertilization applied during this period would not be as effective as a split application with the first $\mathrm{N}$ fertilization already applied in March. Winter wheat plants suffering from $\mathrm{N}$ deficiency during stem elongation should develop a smaller number of grains/ear, thus resulting in grain yield reduction. Nevertheless, plants were able to overcome temporary $\mathrm{N}$ deficiency as well as drought stress without any negative effect on grain yield. This might have been the effect of high $\mathrm{N}$ mineralization potential and water holding capacity of the soils on the experimental sites; however, it showed the potential of modern varieties to compensate for intermediate shortcomings in nutrients and water.

The total amount of $\mathrm{N}$ supplied is more important for yield and quality of cereals than split applications (Müller et al. 1991). Obviously, the effect of different application times becomes more evident only with insufficient $\mathrm{N}$ supply. In the current experiments, there were no negative effects of single $\mathrm{N}$ applications on yield and quality, because total $\mathrm{N}$ supply was adapted to the $\mathrm{N}$ demand of the crops (Düngeverordnung 2009), even though $N$ deficiency symptoms were sometimes visible in winter wheat plants before the $\mathrm{N}$ application at GS 27-32. Obviously, the winter wheat plants were able to overcome temporary $\mathrm{N}$ deficiency situations without negative effects on further growth and yield. Similar results were found by Boelcke (2001), Kücke (2001a) and Sommer (2000) with placed $\mathrm{N}$ applications.

The single broadcast application did not lead to lodging of winter wheat plants in any of the 4 years, even though no growth regulators were applied by farmers. Lodging should be particularly critical for distinct density types of wheat cultivars if the total amount of $\mathrm{N}$ is applied in a single dose. Nevertheless, although some winter wheat cultivars used in the field experiments tended to be density types, no lodging was visible. Obviously, modern winter wheat varieties characterized by high stem strength and reduced shoot length exhibit a decreased disposition to lodging.

No significant differences in grain crude protein were observed between treatments, except in 2010. The same results were found by Kücke (2001b). These findings are, however, in contrast to results of Boelcke (2001), who reported lower crude protein contents after a single placed application. Consequently, Boelcke (2001) recommended an application of $\mathrm{N}$ at GS 49-65 in order to obtain a higher crude protein content. In 2010, crude protein contents were exceptionally high in all treatments indicating a high $\mathrm{N}$-uptake particularly during the latest stage, thus, determining protein storage. Under these conditions a late split application of $\mathrm{N}$ might promote protein storage as shown by the higher protein content in the $3 \times \mathrm{CAN}$ treatment compared to the $1 \times \mathrm{CAN}$ treatment. The high protein content of the single application of urea and UAN solution in 2010 can be explained by reduced mineralization of these fertilizers due to severe dryness in spring inducing a better $\mathrm{N}$ availability during protein storage.

Differences in the general crude protein level, due to year and site, might also explain the differences between independent investigations.

In contrast to the current results, slight differences between the efficiency of the $\mathrm{N}$ fertilizer type urea and CAN were found by Czauderna (1992) and Weimar (2001). One might assume that $N$ fertilization with urea causes lower crude protein when surface applied during drought and high temperatures. Under these conditions gaseous $\mathrm{N}$ losses may reduce the effective $\mathrm{N}$ amount supplied.

The differences in mean crude protein in the individual years were partly explained by weather conditions during head emergence and flowering of winter wheat. For example, the relatively high crude protein content in 2007 can be explained by above average temperatures and rainfall during these late developmental stages. However, there seems to be a negative feedback concerning grain yield and crude protein content. As mentioned above, in 2008, the year with highest grain yield (9.4 tDM/ha), crude protein was lowest $(11.9 \%)$. This might be due to 
a 'dilution effect' as a consequence of optimal growth conditions during tillering and stem elongation, promoting the formation of yield components. Under these conditions, endosperm low in protein is enlarged relative to the germ with high protein content. However, if the yield components 'ears $/ \mathrm{m}^{2}$ ' and 'number of grains/ear' are reduced, probably as a result of spring drought, a high $\mathrm{N}$ availability during grain-filling, depending on $\mathrm{N}$ uptake and remobilization of $\mathrm{N}$, might result in higher crude protein levels.

In wheat, the first $\mathrm{N}$ application is traditionally given at tillering in order to support the number of tillers $/ \mathrm{m}^{2}$. Nitrogen has to be applied at the beginning of tillering around GS 21-25, particularly for plant stand density types, whereas an application at GS 31 should support the number of grains/ear and diminish the reduction of ears $/ \mathrm{m}^{2}$ (Maidl et al. 1998). In the present study, in 2007 and in 2008 no significant differences in the number of ears $/ \mathrm{m}^{2}$ between treatments or cultivars were detected. The reason may be a sufficient $\mathrm{N}$ supply in the soil during tillering. Sommer (2000) also found no differences between a single placed $N$ application and a split application, whereas Kücke (2001b) reported higher numbers of ears $/ \mathrm{m}^{2}$ after a single placed application. In general, plants are able to balance a reduced number of ears $/ \mathrm{m}^{2}$. When ears $/ \mathrm{m}^{2}$ are reduced the number of grains/ear and the thousand grain weight are relatively higher (Niehoff 1978). In 2007, a higher number of grains/ear for the single broadcast application of urea and the single placed application of UAN solution were measured, although April 2007 was extremely dry. It can be assumed that plant development was reduced by drought and the late $\mathrm{N}$ application became effective only after rainfall at the beginning of May.

The thousand grain weight depends on the availability of assimilates, which obviously was not limited in 2008. Kücke (2001a) also found no significant differences between the thousand grain weights of a single placed application and a split application. The amount of assimilates is limited and thousand grain weight reduced only if drought appears during grain filling, causing the plants to mature earlier.

It might be argued that the risk of $\mathrm{NO}_{3}^{-}$-leaching during the vegetation period is increased by a single broadcast application of $\mathrm{N}$ (Gerwing et al. 1979). This might be true for sandy or shallow silty soils, but it is unlikely for deep loamy soils (Beaudoin et al. 2005), especially under the climatic conditions of South-West Germany, where evapotranspiration is quite high during the growth period. The inorganic $\mathrm{N}$ after harvest accounted for c. $20 \mathrm{~kg} \mathrm{~N} / \mathrm{ha}$ in the topsoil and for $5-10 \mathrm{~kg} \mathrm{~N} / \mathrm{ha}$ in the $30-60 \mathrm{~cm}$ layer without significant differences between the fertilization treatments, indicating that no $\mathrm{NO}_{3}^{-}$-leaching occurred during the vegetation period.

The soil samples from the labelled placement bands 10 days after the application of UAN at GS 30-32 showed a concentration of $230 \mathrm{mg}$ mineral $\mathrm{N} / \mathrm{kg}$ soil with a proportion of $77 \% \mathrm{NH}_{4}^{+}$in 2008. According to Sommer (2005), a more beneficial plant morphology compared to conventionally fertilized plants is an advantage of the placed application of $\mathrm{NH}_{4}^{+}$fertilizer. Zhang \& Barber (1993) showed a linear increase in root length density and root surface within the diffusion zone of banded ammonium sulphate depending on the amount supplied. However, in the current study no visual differences between placed and conventionally fertilized plants were found. Additionally, no aggregation of roots around the placed area was visible when digging in the fertilizer bands. This might indicate that $\mathrm{N}$ nutrition of plants was not $\mathrm{NH}_{4}^{+}$-dominated. This assumption goes along with Menge-Hartmann \& Schittenhelm (2008) who found slight physiological reactions typical for $\mathrm{NH}_{4}^{+}$ nutrition during stem elongation, but no differences between $\mathrm{NH}_{4}^{+}$and $\mathrm{NO}_{3}^{-}$-fertilization at later stages of spring wheat development.

The lack of root aggregation around the placed area in the top soil can be advantageous to overcome drought compared to root aggregation in a dry topsoil. A reasonable method to tackle this problem and to maintain a high grain yield compared to broadcast application is to place $N$ fertilizers in deeper soil layers, as was shown by Janzen et al. (1990). In soils with low $\mathrm{N}$ mineralization potential roots will exploit this nutrient patch, since $\mathrm{N}$ (mainly $\mathrm{NO}_{3}^{-}$) triggers root formation towards high concentrations (Drew 1975; Forde \& Lorenzo 2001) and thereby enlarges root to shoot ratio (Marschner 1995).

\section{CONCLUSION}

The current results have shown that a reduction in the number of $\mathrm{N}$ applications to winter wheat with a late first application can be recommended for the climatic conditions of South-West Germany on medium to heavy textured deeply developed soils. If crude protein contents are negligible, i.e. in ethanolwheat production, a single application is sufficient.

The findings strongly call for further investigations under different climatic conditions also including 
other crop species. The worldwide use of split applications of $\mathrm{N}$ fertilizer seems to be built at least partly on obsolete assumptions developed under conditions that are no longer valid, e.g. more flexible varieties and an overall higher level of fertilization compared to decades ago.

Most of the participating farmers have already adopted the reduction in the number of doses from three to two or even single application.

The authors thank the participating farmers for their intense cooperation and Mr. Scott Demyan for improving the English. We also thank the anonymous reviewers for their valuable suggestions. The experiments were supported by the Ministry of Rural Areas and Consumer Protection of the federal state of Baden-Württemberg, Germany.

\section{REFERENCES}

Alcoz, M. M., Hons, F. M. \& Haby, V.A. (1993). Nitrogen fertilization timing effect on wheat production, nitrogen uptake efficiency, and residual soil nitrogen. Agronomy Journal 85, 1198-1203.

Austin, R. B., Bingham, J., Blackwell, R. D., Evans, L.T., Ford, M. A., Morgan, C. L. \& Taylor, M. (1980). Genetic improvements in winter wheat yields since 1900 and associated physiological changes. Journal of Agricultural Science, Cambridge 94, 675-689.

Beaudoin, N., SaAd, J. K., Van Laethem, C., Machet, J.M., MAuCORPS, J. \& MARY, B. (2005). Nitrate leaching in intensive agriculture in Northern France: effect of farming practices, soils and crop rotations. Agriculture, Ecosystems \& Environment 111, 292-310.

BoelCKE, B. (2001). Effekte der N-Injektionsdüngung auf Ertrag und Qualität von Getreide und Raps in Mecklenburg-Vorpommern. Landbauforschung Völkenrode, Sonderheft 245, 45-53.

Bundessortenamt (2012). Beschreibende Sortenliste Getreide, Mais, Öl- und Faserpflanzen, Leguminosen, Rüben, Zwischenfrüchte. Hannover: Bundessortenamt.

CzAuderna, R. (1992). Ertragsbildung und Ertragsstruktur von Winterweizensorten unter besonderer Berücksichtigung des Stickstoffhaushaltes und der Nährstoffaneignung. Ph.D. Thesis, University of Kiel, Germany.

Drew, M. C. (1975). Comparison of the effects of a localized supply of phosphate, nitrate, ammonium and potassium on the growth of the seminal root system, and the shoot, in barley. New Phytologist 75, 479-490.

DüNGEVERORDNUNG (2009). Verordnung über die Anwendung von Düngemitteln, Bodenhilfsstoffen, Kultursubstraten und Pflanzenhilfsmitteln nach den Grundsätzen der Guten Fachlichen Praxis beim Düngen. Paderborn, Germany: Verlag GmbH.

Fischbeck, G., Dennert, J. \& Müller, R. (1990). N-Dynamik des Bodens, Ertragsbildung und Stickstoffentzug von Winterweizen bei unterschiedlicher Höhe und
Verteilung der mineralischen N-Düngung. Journal of Agronomy \& Crop Science 164, 297-311.

Forde, B. \& Lorenzo, H. (2001). The nutritional control of root development. Plant and Soil 232, 51-68.

Fox, R. H., Kern, J. M. \& Piekielek, W. P. (1986). Nitrogen fertilizer source, and method and time of application effects on no-till corn yields and nitrogen uptakes. Agronomy Journal 78, 741-746.

Gerwing, J. R., Caldwell, A. C. \& Goodroad, L. L. (1979). Fertilizer nitrogen distribution under irrigation between soil, plant, and aquifer. Journal of Environmental Quality $\mathbf{8}$, 281-284.

HamiD, A. (1972). Efficiency of $N$ uptake by wheat, as affected by time and rate of application, using $N^{15}$-labelled ammonium sulphate and sodium nitrate. Plant and Soil 37, 389-394.

HaRTMAN, M. D. \& NYBORG, M. (1989). Effect of early growing season moisture stress on barley utilization of broadcastincorporated and deep-banded urea. Canadian Journal of Soil Science 69, 381-389.

Janzen, H. H., Lindwall, C. W. \& Roppel, C. J. (1990). Relative efficiency of point-injection and surface applications for $\mathrm{N}$ fertilization of winter wheat. Canadian Journal of Soil Science 70, 189-201.

Kanwar, R.S., Baker, J.L. \& Baker, D. G. (1988). Tillage and split $\mathrm{N}$-fertilization effects on subsurface drainage water quality and crop yields. Transactions of the ASAE 31, 453-461.

KüCKE, M. (2001a). Biomasseproduktion und N-Effizienz von Winterweizen und Winterroggen nach $\mathrm{N}$ Injektionsdüngung: Feldversuchsergebnisse 2001. Landbauforschung Völkenrode, Sonderheft 245, 81-92.

KüCKE, M. (2001b). Ertrag und Kornqualität von Winterweizen und Winterroggen nach N-Injektionsdüngung: Feldversuchsergebnisse 2001. Landbauforschung Voelkenrode, Sonderheft 245, 69-80.

LiU, X. J., Mosier, A. R., Halvorson, A.D. \& ZhanG, F.S. (2006). The impact of nitrogen placement and tillage on $\mathrm{NO}, \mathrm{N}_{2} \mathrm{O}, \mathrm{CH}_{4}$ and $\mathrm{CO}_{2}$ fluxes from a clay loam soil. Plant and Soil 280, 177-188.

Maidl, F. X., Panse, A., Dennert, J., Ruser, R. \& Fischbeck, G. (1996). Effect of varied $\mathrm{N}$ rates and $\mathrm{N}$ timings on yield, $\mathrm{N}$ uptake and fertilizer $\mathrm{N}$ use efficiency of a six-row and a two-row winter barley. European Journal of Agronomy 5, 247-257.

Maidl, F. X., Sticksel, E., Retzer, F. \& Fischbeck, G. (1998). Effect of varied $\mathrm{N}$-fertilization on yield formation of winter wheat under particular consideration of mainstems and tillers. Journal of Agronomy and Crop Science 180, 15-22.

Marschner, H. (1995). Mineral Nutrition of Higher Plants, 2nd edn, London: Academic Press.

Menge-Hartmann, U. \& Schittenhelm, S. (2008). Depotstabilität von lokal injiziertem Ammonium und Einfluss auf den Metabolismus von Sommerweizen. Landbauforschung $\mathrm{VTI}$ Agriculture and Forestry Research 58, 235-246.

Müller, S., Ansorge, H. \& Weigert, I. (1991). Einfluss der Stickstoffdüngung auf Ertrag, Ertragsstruktur und $\mathrm{N}$-Verwertung von Winterweizen - Möglichkeiten und 
Grenzen der Bestandesführung. Zeitschrift für Pflanzenernährung und Bodenkunde 154, 115-119.

NieHOFF, K.-H. (1978). Möglichkeiten der Kompensation witterungsbedingter Schwankungen der Ertragsstruktur einiger Weizen-und Gerstensorten durch variierte N-Ernährung. Ph.D. Thesis, University of Kiel, Germany.

Piepho, H.P. (2012). A SAS macro for generating letter displays of pairwise mean comparisons. Communications in Biometry and Crop Science 7, 4-13.

Piepho, H.-P., Richter, C., Spilke, J., Hartung, K., Kunick, A. \& THÖLE, H. (2011). Statistical aspects of on-farm experimentation. Crop and Pasture Science 62, 721-735.

Schittenhelm, S. \& Menge-Hartmann, U. (2006). Yield formation and plant metabolism of spring barley in response to locally injected ammonium. Journal of Agronomy and Crop Science 192, 434-444.

SOMmer, K. (2000). CULTAN-cropping system: fundamentals, state of development and perspectives. In Nitrogen in a Sustainable Ecosystem: From the Cell to the Plant (Eds M. A. Martins-Loucao \& S. H. Lips), pp. 361-375. Leiden, The Netherlands: Backhuys Publishers.

SOMmer, K. (2005). CULTAN-Düngung, Physiologisch, ökologisch, ökonomisch optimiertes Düngungsverfahren für Ackerkulturen, Grünland, Gemüse, Zierpflanzen und Obstgehölze. Gelsenkirchen, Germany: Verlag Th. Mann.

SOMmer, K. \& SCHerer, H.W. (2009). Source/sink-relationships in plants as depending on ammonium as 'CULTAN', nitrate or urea as available nitrogen fertilizers. Acta Horticulturae 835, 65-87.

Sticksel, E., Maidl, F.-X., Retzer, F., Dennert, J. \& Fischbeck, G. (2000). Efficiency of grain production of winter wheat as affected by $\mathrm{N}$ fertilisation under particular consideration of single culm sink size. European Journal of Agronomy 13, 287-294.

Teller, G. L. (1932). Non-protein nitrogen compounds in cereals and their relation to the nitrogen factor for protein in cereals and bread. Cereal Chemistry 9, 261-274. Cited in: Lopez-Bellido, R. J., Shepherd, C. E. \& Barraclough, P. B. (2004). Predicting post-anthesis $N$ requirements of bread wheat with a Minolta SPAD meter. European Journal of Agronomy 20, 313-320.

Varshney, P., Kanwar, R.S., Baker, J.L. \& Anderson, C. E. (1993). Tillage and nitrogen management effects on nitrate-nitrogen in the soil profile. Transactions of the ASAE 36, 783-789.

VDLUFA (2007). Methodenbuch Band I, Die Untersuchung von Böden', 4. Darmstadt, Germany: VDLUFA-Verlag.

Wasser- und Bodenatlas Baden-Württemberg (2012). Umweltministerium Baden-Württemberg. Stuttgart, Germany: Landesanstalt für Umwelt, Messungen und Naturschutz Baden-Württemberg.

WeIMAR, S. (2001). Untersuchungen zur N-Nüngung nach dem CULTAN-Verfahren bei Getreide, Zuckerrüben und Kartoffeln in Rheinland-Pfalz. Landbauforschung Völkenrode, Sonderheft 245, 23-44.

Zadoks, J. C., Chang, T. T. \& KonZAK, C. F. (1974). A decimal code for the growth stages of cereals. Weed Research 14, $415-421$.

ZhANG, J. \& BARBER, S.A. (1993). Corn root distribution between ammonium fertilized and unfertilized soil. Communications in Soil Science and Plant Analysis 24, 411-419. 